\title{
Z3 Research Sware \\ Wheat Growth As Affected By Planting Density, Planting Time And Nitrogen Application
}

Patrick Mashiqa

Department of Agricultural Research

Flora Pule-Meulenberg

Botswana University of Agriculture and Natural Resources

Samodimo Ngwako ( $\sim$ sngwako@buan.ac.bw )

Botswana University of Agriculture and Natural Resources

\section{Research Article}

Keywords: Anthesis, flowering time, glutens, protein profiling, physiological maturity

Posted Date: January 31st, 2022

DOI: https://doi.org/10.21203/rs.3.rs-1276650/v1

License: (1) This work is licensed under a Creative Commons Attribution 4.0 International License.

Read Full License 


\section{Abstract}

The growth and development of wheat and quality of wheat flour is dependent on the genotype, fertilizer application, sowing date and plant density. Therefore, plant growth and protein content studies were conducted on two wheat genotypes during the winter planting seasons of 2015 and 2016. The experiment was laid out in a Randomised Complete Block Design in a split-split-plot arrangement, with the main plots being two wheat genotypes; sub plots being two plant density treatments, sub-sub plots being five nitrogen doses and sub-sub-sub plots of two planting dates, replicated three times. The application of $125 \mathrm{~kg} / \mathrm{ha}$ nitrogen increased the number of days to anthesis, grain protein content and plant height. Early planting reduced days to emergence but delayed days to anthesis and physiological maturity, whereas the protein content and plant height were increased by early planting. The leaf dry mass, crop growth rate and net assimilation rate were similar at each crop stage for the planting densities, and they were increased at $125 \mathrm{~kg} / \mathrm{ha}$ application of nitrogen. The genotypes showed the presence of glutens of both high molecular and low molecular weight which are likely to contain genes that supports good baking quality of flour. The interaction of plant density, planting time and nitrogen at $125 \mathrm{~kg} / \mathrm{ha}$ contributed more protein bands with low and high molecular weight glutenin's in wheat genotypes.

\section{Introduction}

The world population is increasing at an alarming rate but the land for cultivation of arable crops is decreasing. This calls for cultivation of high value crops such as wheat (Triticum aestivum L.) to increase yield per unit area. Wheat is important as it provides more protein than any other cereal crops [1]. Currently wheat is not grown in Botswana, as such the country import wheat and for it to start producing wheat, agronomic studies are needed to determine varieties and optimal planting conditions.

The wheat grains are ground into flour, and the greatest portion of the wheat flour is used for bread making. The grain protein content and composition of wheat is affected by both genotype and the environment in which the crop is grown. Nitrogen is applied to plants to improve crop quality and to increase yield, and its application also contributes considerably to protein content, especially when fertilizer rates satisfy the requirements of both yield and protein formation [2]. The correct fertilizer application especially nitrogen is important to achieve higher yields and good grain quality of wheat [3].

In addition to grain protein content, the presence of gluten in wheat makes it unique [4]. The glutens are important flour quality determinants because they are responsible for dough extensibility and elasticity of wheat flour, which determine the processing qualities of a wide range of wheat products [5]. The amount of gluten in wheat is normally influenced by the environment and the grain protein content, but also the genotype [6]. Wheat grain protein can be divided into two groups: non-gluten proteins (albumin and globulins) and gluten proteins (gliadins and glutenin's). Gluten protein subunits are divided into High Molecular Weight Glutenin (HMW-GS) and Low Molecular Weight Glutenin's (LMW-GS), [7]. The molecular 
structure of the glutens determines the quality of the bread and controls the interactions of gluten subfractions during processing [8].

Besides regular nutrition of plants for achieving high yields, the genotype, plant density and planting time also play an important role in good grain quality for bread making in wheat [3,9]. Optimum densities vary between areas, climatic conditions, planting time and varieties. Since cultivars genetically differ for yield components, individual cultivars need to be tested for proper density [10]. Management practices play a vital role in determining yield and end-use quality of wheat. Therefore, the aim of this research was to investigate the influence of plant density, nitrogen rate, and planting time on plant growth and the protein content as well as the molecular profile of the grain proteins in two wheat genotypes.

\section{Materials And Methods}

\subsection{Experimental site}

The field studies were conducted at the Botswana University of Agriculture and Natural Resources (BUAN), Sebele, Gaborone, over the winter planting seasons of 2015 and 2016 under irrigation, in sandy loam soil. Botswana is arid to semi-arid region with rainfall in the summer and dry winters.

\subsection{Experimental design and treatments}

The experiment was laid out in a Randomised Complete Block Design (RCBD) under split-split-plot arrangement with three replications. The main plot consisted of two spring wheat genotypes, Baviaans and 14SAWYT308; and sub plots comprised of two plant density treatments, $(0.2 \mathrm{~m} \times 0.15 \mathrm{~m}) 333,333$ plants/ha and $(0.2 \mathrm{~m} \times 0.2 \mathrm{~m}) 250000$ plants/ha; sub-sub plots were five nitrogen doses, $0 \mathrm{~kg} / \mathrm{ha}\left(\mathrm{N}_{0}\right), 50$ $\mathrm{kg} / \mathrm{ha}\left(\mathrm{N}_{50}\right), 75 \mathrm{~kg} / \mathrm{ha}\left(\mathrm{N}_{75}\right), 125 \mathrm{~kg} / \mathrm{ha}\left(\mathrm{N}_{125}\right)$ and $200 \mathrm{~kg} / \mathrm{ha}\left(\mathrm{N}_{200}\right)$; and sub-sub-sub plots of two planting dates, $21^{\text {st }}$ April and $05^{\text {th }}$ May. The nitrogen fertilizer applied was urea $(46.5 \% \mathrm{~N})$ and half of the nitrogen was applied at the time of planting while the remaining half was applied one week after seedling emergence. Two weeks after sowing, thinning was done to one plant per hill. Phosphorus (single super phosphate, $9 \%$ ) was applied at sowing at the rate of $55 \mathrm{~kg} / \mathrm{ha}$. Irrigation was done two times a week for two hours each time to field capacity.

\subsection{Growth parameters}

At $28,56,84,112$, and 140 days after sowing (DAS), three plants were randomly selected from each plot and measurements on leaf dry mass, crop growth rate, net assimilation rate, and leaf area were taken. The leaves from the three plants selected at random from each sub-plot were dried in the oven at $70 \pm 5$ $\mathrm{C}^{\circ}$ until reaching a constant weight after 48 hours and weighed to get the leaf dry mass. The leaves from each plant were placed on an electronic LI-3100 leaf area meter (USA-model), to get the leaf area. Leaf area index (LAl) for each experimental unit was computed using leaf area values as the ratio of total leaf area to land for each experimental unit [11]. 
Leaf area duration (LAD) was calculated by the formula as proposed by [12]. The LAD was determined starting from 28 DAS up to 112 DAS.

$\mathrm{LAD}=\frac{\left[\left(\mathrm{LAI}_{1}+\mathrm{LAI}_{2}\right) \times\left(\mathrm{t}_{2}-\mathrm{t}_{1}\right)\right]}{2}$

$\mathrm{LAl}_{1}=$ leaf area index at $\mathrm{t}_{1}, \mathrm{LAl}_{2}=$ leaf area index at $t_{2}, \mathrm{~T}_{1}=$ time for first observation, $\mathrm{T}_{2}=$ time for second observation

The dry matter accumulation was determined starting from 28 DAS up to 140 DAS by taking three plants at random from each sub-plot. After taking samples they were dried in the oven at $70 \pm 5 \mathrm{C}^{\circ}$ until reaching a constant weight after 48 hours. Then samples dry weight was calculated and used to find out crop growth rate (CGR) by the formula as given by [12].

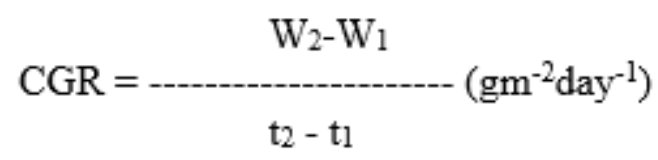

$\mathrm{W}_{2}=$ dry weight per unit land area $\left(\mathrm{gm}^{-2}\right)$ at second harvest, $\mathrm{W}_{1}=$ dry weight per unit land area $\left(\mathrm{gm}^{-2}\right)$ at first harvest, $T_{2}=$ time taken to second harvest, $T_{1}=$ time to taken first harvest

The net assimilation rate (NAR) was determined by the formula as stated by [12]. The NAR was determined starting from 28 DAS up to 112 DAS using the same leaves as for CGR.

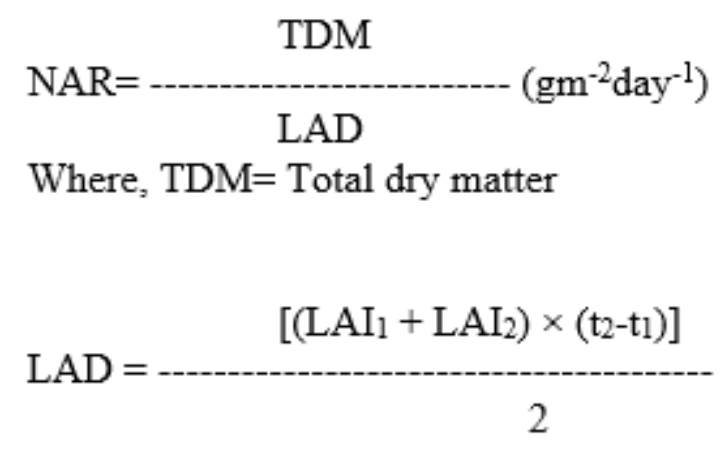

$\mathrm{LAl}_{1}=$ leaf area index at $\mathrm{t}_{1}, \mathrm{LAl}_{2}=$ leaf area index at $t_{2}, \mathrm{~T}_{1}=$ time for first observation, $\mathrm{T}_{2}=$ time for second observation

\subsection{Phenological parameters}

The days to emergence was calculated as difference between date of emergence and date of sowing; days to anthesis was computed as difference between date of anthesis and date of sowing; days to 
maturity was computed as difference between the date of physiological maturity and date of sowing, and plant height at maturity was measured using a ruler from the base of the node to the top of the plant.

\subsection{Grain protein content}

The content of nitrogen on grain samples was determined by micro Kjeldahl method described by [13]. Protein percentage was determined by multiplying grain nitrogen content by 5.7 , which is the appropriate factor worked out for wheat [14].

Nitrogen $(\%)=\underline{\text { Volume of acid used } \times 0.0014 \times 250 \times 100}$

Sample weight $\times 10 \mathrm{ml}$

Crude protein $(\%)=\%$ Nitrogen $\times 5.7$

\subsection{Protein profiling}

Five wheat seeds from each treatment were ground with an electric laboratory grinder (model A10 57Kinematica Switzerland) and $10 \mathrm{mg}$ of the seed flour was taken into a $1.5 \mathrm{~mL}$ micro tube. A $400 \mu \mathrm{L}$ of protein extraction buffer ( $1 \% \beta$ - mecaptoethanol, $5 \mathrm{M}$ urea, $0.2 \% \mathrm{SDS}, 0.05 \mathrm{M}$ tris) and $0.0001 \%$ bromophenol blue were added and content vortexed for 5 minutes. The crude homogenates were centrifuged using a micro centrifuge set at $13000 \mathrm{rpm}$ at room temperature for 10 minutes. The separation gel (12.25\%) was prepared using $5 \mathrm{~mL}$ Solution A (3.0 M Tris-HCL pH 9.0, 0.4\% SDS), $7.5 \mathrm{ml}$ Solution C (30\% Acrylamide, Acrylamide/Bis $=(30: 0.8), 200 \mu \mathrm{L}$ of $10 \%$ Ammonium per sulphate (APS)), $7.5 \mathrm{~mL}$ of distilled water and $15 \mu \mathrm{L}$ of TEMED. Glass plates were cleaned with $70 \%$ ethanol and fixed with clips, and separation gel poured to the cell layered with water, and after 30 minutes distilled water was removed and stacking gel added. A comb was inserted into stacking gel, and the supernatant was separated and $15 \mu \mathrm{L}$ of each sample (supernatant) along with protein molecular weight marker (11 - $190 \mathrm{kDa}$ broad range) was loaded into gels. Electrophoresis was done at constant voltage of 100 volts, until the dye front reached the bottom of the gel. The gels were then removed from plates, dyed in staining solution (Coomasie Brilliant Blue - R250, 6\% Acetic acid, 44\% methanol) and shaken using an electric shaker (model MK 161- Japan) until protein bands appeared (2 hours). Gels were then washed with distilled water for 5 minutes then transferred to de-staining solution ( $20 \%$ methanol, and $5 \%$ acetic acid) then shaken in electronic shaker until protein bands appeared ( 2 hours). The gel was observed under gel documentation system Bio-RAD with white light illuminator and photographed.

\subsection{Data analysis}

Data on agronomic traits were subjected to an Analysis of Variance (ANOVA) using STATISTICA package, version 13.1 after testing for normality. Where there were significant differences, mean separation was done using the Least Significance Difference (LSD) method. For protein profiling, data electropherograms for each treatment were scored and the presence (1) or absence (0) of each band recorded and entered 
into a binary data matrix, and similarity matrix generated was used to construct dendrogram using a statistical package NTSYC-PC, Version 2.0 [15].

\section{Results}

The genotype, plant density and the application of nitrogen fertiliser had no effect on the number of days to emergence of wheat in both years, but planting date affected the number of days to emergence, with earlier planted wheat (21 April), emerging quicker (Table 1). The wheat genotypes and planting density had no effect on number of days to anthesis except for plant density in 2016. Applying nitrogen increased the number of days to anthesis and plants that received $125 \mathrm{~kg} / \mathrm{ha}$ of nitrogen (N) exhibited the highest number of days to anthesis, and plants grown on 21st April reached the anthesis later than those planted on 5th May in both years. The days to physiological maturity was not affected by genotypes, planting density and nitrogen application. Planting date significantly affected days to physiological maturity with the earlier planted plants taking longer to reach physiological maturity in both years. 
Table 1

Days to emergence, days to anthesis and days to physiological maturity in wheat

\begin{tabular}{|c|c|c|c|c|c|c|c|}
\hline \multirow[t]{2}{*}{ Treatments } & & \multicolumn{2}{|c|}{$\begin{array}{l}\text { Days to } \\
\text { emergence }\end{array}$} & \multicolumn{2}{|c|}{ Days to anthesis } & \multicolumn{2}{|c|}{$\begin{array}{l}\text { Days to } \\
\text { physiological } \\
\text { maturity }\end{array}$} \\
\hline & & 2015 & 2016 & 2015 & 2016 & 2015 & 2016 \\
\hline \multirow[t]{2}{*}{ Genotypes } & Baviaans & $6.33^{a}$ & $5.98^{\mathrm{a}}$ & $86.33^{a}$ & $84.52^{\mathrm{a}}$ & $143.10^{a}$ & $144.10^{\mathrm{a}}$ \\
\hline & 14SAWYT308 & $6.52^{\mathrm{a}}$ & $6.35^{\mathrm{a}}$ & $86.42^{\mathrm{a}}$ & $84.63^{a}$ & $143.10^{a}$ & $144.10^{\mathrm{a}}$ \\
\hline \multirow{2}{*}{$\begin{array}{l}\text { Planting density } \\
\text { (plants/ha) }\end{array}$} & 333,333 & $6.63^{a}$ & $6.33^{\mathrm{a}}$ & $86.43^{\mathrm{a}}$ & $86.23^{b}$ & $143.20^{a}$ & $144.10^{\mathrm{a}}$ \\
\hline & 250,000 & $6.23^{\mathrm{a}}$ & $6.00^{\mathrm{a}}$ & $86.32^{\mathrm{a}}$ & $84.95^{a}$ & $143.00^{a}$ & $144.00^{\mathrm{a}}$ \\
\hline \multirow[t]{5}{*}{ Nitrogen Rate } & 0 & $6.14^{\mathrm{a}}$ & $6.17^{a}$ & $84.70^{c}$ & $83.71^{a b}$ & $143.25 a$ & $144.00^{\mathrm{a}}$ \\
\hline & 50 & $6.29^{a}$ & $5.92^{\mathrm{a}}$ & $86.40^{\mathrm{b}}$ & $84.58^{\mathrm{ab}}$ & $143.00 \mathrm{a}$ & $144.33^{\mathrm{a}}$ \\
\hline & 75 & $6.25^{\mathrm{a}}$ & $6.08^{a}$ & $86.5^{\mathrm{b}}$ & $84.54^{\mathrm{ab}}$ & $143.00 \mathrm{a}$ & $144.00^{\mathrm{a}}$ \\
\hline & 125 & $6.67^{a}$ & $6.25^{\mathrm{a}}$ & $87.45^{\mathrm{a}}$ & $85.17^{a}$ & $143.00 \mathrm{a}$ & $144.00^{\mathrm{a}}$ \\
\hline & 200 & $6.50^{\mathrm{a}}$ & $6.42^{\mathrm{a}}$ & $86.8^{\mathrm{b}}$ & $84.88^{a}$ & $143.25 a$ & $143.92^{\mathrm{a}}$ \\
\hline \multirow[t]{5}{*}{ Planting date } & 21 April & $6.08^{b}$ & $5.93^{b}$ & $88.23^{a}$ & $85.48^{\mathrm{a}}$ & $146.00^{a}$ & $147.97^{\mathrm{a}}$ \\
\hline & 05 May & $6.77^{\mathrm{a}}$ & $6.40^{\mathrm{a}}$ & $84.52^{b}$ & $83.67^{b}$ & $140.20^{b}$ & $140.13^{b}$ \\
\hline & Mean & 6.43 & 6.17 & 86.38 & 84.58 & 143.10 & 144.10 \\
\hline & CV \% & 17.52 & 17.67 & 0.98 & 2.04 & 0.54 & 0.52 \\
\hline & LSD & 0.41 & 0.39 & 0.31 & 0.63 & 0.28 & 0.27 \\
\hline
\end{tabular}

The genotypes, nitrogen application and planting date significantly affected plant height and grain protein content in 2015 and 2016 (Table 2). The genotype, 14SAWYT308 exhibited higher plant height and protein content in both years compared to Baviaans. The early planted crops gave higher plant height and protein content, as well as the application of $125 \mathrm{~kg} / \mathrm{ha} \mathrm{N}$. The highest plant density showed the highest plant height in both seasons. 
Table 2

Grain protein content (GPC) and plant height in wheat genotypes

\section{Treatments}

\begin{tabular}{|c|c|c|c|c|c|}
\hline & & 2015 & 2016 & 2015 & 2016 \\
\hline \multirow[t]{2}{*}{ Genotypes } & Baviaans & $\begin{array}{l}12.3 \\
\pm 0.1 \mathrm{~b}\end{array}$ & $12.7 \pm 0.1 b$ & $76.6 \pm 1.3 b$ & $76.3 \pm 1.5 b$ \\
\hline & 14SAWYT308 & $\begin{array}{l}12.8 \\
\pm 0.2 \mathrm{a}\end{array}$ & $13.1 \pm 0.1 a$ & $79.2 \pm 1.4 a$ & $79.2 \pm 1.4 a$ \\
\hline \multirow[t]{2}{*}{$\begin{array}{l}\text { Planting density } \\
\text { (plants/ha) }\end{array}$} & 333,333 & $\begin{array}{l}12.6 \\
\pm 0.2 \mathrm{a}\end{array}$ & $12.9 \pm 0.1 \mathrm{a}$ & $79.4 \pm 1.4 a$ & $79.0 \pm 1.6 a$ \\
\hline & 250,000 & $\begin{array}{l}12.5 \\
\pm 0.1 \mathrm{a}\end{array}$ & $12.9 \pm 0.1 a$ & $76.5 \pm 1.3 b$ & $76.5 \pm 1.3 b$ \\
\hline \multirow[t]{5}{*}{ Nitrogen Rate } & 0 & $\begin{array}{l}11.2 \\
\pm 0.1 \mathrm{~d}\end{array}$ & $11.8 \pm 0.1 e$ & $66.5 \pm 0.6 \mathrm{e}$ & $62.3 \pm 0.7 e$ \\
\hline & 50 & $\begin{array}{l}12.5 \\
\pm 0.1 \mathrm{c}\end{array}$ & $13.0 \pm 0.1 \mathrm{c}$ & $70.8 \pm 0.7 d$ & $72.5 \pm 0.6 d$ \\
\hline & 75 & $\begin{array}{l}13.2 \\
\pm 0.1 \mathrm{~b}\end{array}$ & $13.4 \pm 0.1 b$ & $75.2 \pm 0.5 c$ & $77.4 \pm 0.4 \mathrm{c}$ \\
\hline & 125 & $\begin{array}{l}13.6 \\
\pm 0.4 a\end{array}$ & $13.7 \pm 0.2 \mathrm{a}$ & $94.8 \pm 0.8 a$ & $94.2 \pm 1.1 \mathrm{a}$ \\
\hline & 200 & $\begin{array}{l}12.3 \\
\pm 0.1 \mathrm{c}\end{array}$ & $12.7 \pm 0.1 d$ & $82.6 \pm 0.6 b$ & $82.7 \pm 0.7 b$ \\
\hline \multirow[t]{2}{*}{ Planting date } & 21 April & $12.8 \pm 0.2 \mathrm{a}$ & $13.1 \pm 0.1 \mathrm{a}$ & $78.7 \pm 1.4 a$ & $78.8 \pm 1.6 a$ \\
\hline & 05 May & $\begin{array}{l}12.3 \\
\pm 0.1 \mathrm{~b}\end{array}$ & $12.7 \pm 0.1 b$ & $77.2 \pm 1.3 b$ & $76.7 \pm 1.3 b$ \\
\hline \multirow[t]{7}{*}{ F statistics } & Genotype & $21.73^{\star \star \star}$ & $54.9 * \star \star$ & $37.1^{\star \star \star}$ & 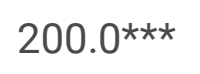 \\
\hline & Planting density & $0.56 \mathrm{~ns}$ & $0.6 \mathrm{~ns}$ & $44.5^{\star \star \star}$ & $144.7^{\star \star \star}$ \\
\hline & Nitrogen rate & $53.78^{\star \star \star}$ & $114.4^{\star \star \star}$ & $575.3^{\star \star \star}$ & $2731.3^{\star \star \star}$ \\
\hline & Planting date & $21.38^{\star \star \star}$ & $51.7^{\star \star \star}$ & 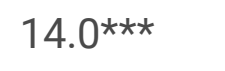 & $117.1^{\star \star \star}$ \\
\hline & $\begin{array}{l}\text { Genotype density*N } \\
\text { rate*date }\end{array}$ & $2.20 \mathrm{~ns}$ & $4.9 * \star$ & $0.5 \mathrm{~ns}$ & $6.2^{\star \star \star}$ \\
\hline & CV \% & 4.91 & 2.58 & 2.59 & 1.21 \\
\hline & LSD & 0.22 & 0.12 & 0.73 & 0.34 \\
\hline
\end{tabular}


The highest plant density showed the highest leaf dry mass but did not differ significantly to that of the lowest plant density at each measuring time (Figure 1). The leaf dry matter values increased from early development stage (28 DAS) until they reached maximum values at flowering stage (84 DAS), and thereafter dropped until plants reached maturity. Also, the crop growth rate showed peak values at flowering time, 84 DAS (Figure 2).

The net assimilation rate (NAR) was the same at each growth stage for both planting densities (Figure 3). At 56 DAS there was a decline in the NAR, and then it increased at flowering and slightly decreased towards maturity.

The application of nitrogen enhanced leaf dry matter of wheat genotypes (Figure 4). There was more leaf dry mass accumulated with the application of $125 \mathrm{~kg} / \mathrm{ha}$ at each sampling time (Figure 4), but the means did not differ significantly from each other $(p \leq 0.05)$ for a sampling time. Leaf dry mass accumulation increased steadily from the vegetative stage until it reached peak at flowering stage (84 DAS), thereafter reduced gradually until physiological maturity (140 DAS).

The crop growth rate and net assimilation rate showed the highest values at flowering time (Figure 5 and 6). The application of $125 \mathrm{~kg} / \mathrm{ha}$ nitrogen increased the crop growth rate and the net assimilation rate at flowering and maturity time.

The clustering of genotype, nitrogen, plant density, and planting date interactions based on 40 treatments, using Un-weighted Pair Group Method with Arithmetic mean cluster analysis (UPGMA) showed four main clusters (labelled 1, 2, 3 and 4) demarcated at coefficient of approximately 0.63 (Figure 7). Cluster 1 consisted of treatments $N_{50} D_{1} D_{2} V_{2}$, and $N_{75} D n_{2} D_{2} V_{1}$, where the protein bands were similar. Cluster 2 comprised of treatments $N_{75} D n_{1} D t_{1} V_{2}$ only, while cluster 4 comprised of $N_{0} D n_{1} D t_{1} V_{2}$ and $N_{50} D n_{1} D t_{1} V_{2}$, and likewise, they showed similarity in protein bands. Most of the genotype, plant density, nitrogen rate and planting date treatments interactions were found under main cluster 3 , comprising 35 combinations.

The banding patterns of wheat proteins with genotype Baviaans from 21 st April at 333,333 plants/ha density with nitrogen at the rate of $125 \mathrm{~kg} / \mathrm{ha}\left(\mathrm{N}_{125} \mathrm{Dn}_{1} \mathrm{Dt}_{1} \mathrm{~V}_{2}\right)$, Genotype Baviaans planted on the $21 \mathrm{st}$ April at 250,000 plants/ha applied $75 \mathrm{~kg} / \mathrm{ha}$ of $\mathrm{N}\left(\mathrm{N}_{75} \mathrm{Dn}_{2} \mathrm{Dt}_{1} \mathrm{~V}_{2}\right)$, and Genotype Baviaans from 5th May planting date at 333,333 plants/ha with no nitrogen $\left(N_{0} D_{1} D_{2} V_{2}\right)$ are shown in Figure 8. Their protein patterns were detected to be similar and were all under main cluster 3 . Binary data matrix analysis showed that protein bands from electropherogram had molecular weight of $25 \mathrm{kDa}, 32 \mathrm{kDa}, 58 \mathrm{kDa}$, and $75 \mathrm{kDa}$.

A total of 70 protein bands were detected and were identified by common characteristics from main cluster 3 (Table 3 ). The highest number of bands (17) were observed in sub-cluster $F$, defined by (all Baviaans genotype), represented by treatments $N_{125} D n_{1} D t_{1} V_{2}, N_{75} D n_{2} D t_{1} V_{2}$, and $N_{0} D n_{1} D t_{2} V_{2}$. Subclusters $E$ and $F$ contain $125 \mathrm{~kg} / \mathrm{ha} \mathrm{N}$ and account for $47 \%$ (33/70) of total protein bands, and the $\mathrm{N}_{125}$ in this experiment had higher protein content. Minimum number of protein bands (4) was obtained in sub- 
cluster $\mathrm{C}$ identified by all Baviaans genotypes from $21 \mathrm{st}$ April planting date $\left(\mathrm{N}_{0} \mathrm{Dn}_{1} D t_{1} \mathrm{~V}_{1}\right.$, and $\left.\mathrm{N}_{200} \mathrm{Dn}_{1} \mathrm{Dt}_{1} \mathrm{~V}_{1}\right)$.

Table 3

Sub-clusters based on protein bands characteristics.

\begin{tabular}{|c|c|c|c|}
\hline $\begin{array}{l}\text { Sub- } \\
\text { cluster }\end{array}$ & $\begin{array}{l}\text { No. of protein } \\
\text { bands }\end{array}$ & Cluster identification characteristics & $\begin{array}{l}\text { Cluster members } \\
\text { (Treatments) }\end{array}$ \\
\hline \multirow[t]{2}{*}{ A } & 7 & $\begin{array}{l}\text { Genotype Baviaans planted at 250,000 } \\
\text { plants/ha density }\end{array}$ & $\mathrm{N}_{50} \mathrm{Dn}_{2} \mathrm{Dt}_{2} \mathrm{~V}_{1}$ \\
\hline & & & $\mathrm{N}_{75} \mathrm{Dn}_{2} \mathrm{Dt}_{1} \mathrm{~V}_{1}$ \\
\hline \multirow[t]{2}{*}{ B } & 6 & $\begin{array}{l}250,000 \text { plants/ha density crops from } 05 \text { th } \\
\text { May planting date }\end{array}$ & $\mathrm{N}_{0} \mathrm{Dn}_{2} \mathrm{Dt}_{2} \mathrm{~V}_{1}$ \\
\hline & & & $\mathrm{N}_{200} \mathrm{Dn}_{2} \mathrm{Dt}_{2} \mathrm{~V}_{2}$ \\
\hline \multirow[t]{2}{*}{ C } & 4 & $\begin{array}{l}\text { Baviaans genotype from 21st April planting } \\
\text { date }\end{array}$ & $\mathrm{N}_{0} \mathrm{Dn}_{1} \mathrm{Dt}_{1} \mathrm{~V}_{1}$ \\
\hline & & & $\mathrm{N}_{200} \mathrm{Dn}_{2} \mathrm{Dt}_{1} \mathrm{~V}_{1}$ \\
\hline \multirow[t]{3}{*}{ D } & 10 & Crops at density of 333,333 plants/ha & $\mathrm{N}_{200} \mathrm{Dn}_{1} \mathrm{Dt}_{1} \mathrm{~V}_{2}$ \\
\hline & & & $\mathrm{N}_{125} \mathrm{Dn}_{1} \mathrm{Dt}_{2} \mathrm{~V}_{1}$ \\
\hline & & & $\mathrm{N}_{125} \mathrm{Dn}_{1} \mathrm{Dt}_{1} \mathrm{~V}_{1}$ \\
\hline \multirow[t]{3}{*}{$\mathrm{E}$} & 16 & All crops from 21st April planting date & $\mathrm{N}_{125} \mathrm{Dn}_{2} \mathrm{Dt}_{1} \mathrm{~V}_{1}$ \\
\hline & & & $\mathrm{N}_{200} \mathrm{Dn}_{2} \mathrm{Dt}_{1} \mathrm{~V}_{2}$ \\
\hline & & & $\mathrm{N}_{50} \mathrm{Dn}_{1} \mathrm{Dt}_{1} \mathrm{~V}_{1}$ \\
\hline \multirow[t]{3}{*}{$\mathrm{F}$} & 17 & All Baviaans genotype crops & $\mathrm{N}_{125} \mathrm{Dn}_{1} \mathrm{Dt}_{1} \mathrm{~V}_{2}$ \\
\hline & & & $\mathrm{N}_{75} \mathrm{Dn}_{2} \mathrm{Dt}_{1} \mathrm{~V}_{2}$ \\
\hline & & & $\mathrm{N}_{0} \mathrm{Dn}_{1} \mathrm{Dt}_{2} \mathrm{~V}_{2}$ \\
\hline \multirow[t]{2}{*}{ G } & 10 & $\begin{array}{l}\text { Genotype 14SAWYT308 planted at density of } \\
333,333 \text { plants/ha }\end{array}$ & $\mathrm{N}_{50} \mathrm{Dn}_{1} \mathrm{Dt}_{1} \mathrm{~V}_{2}$ \\
\hline & & & $\mathrm{N}_{0} \mathrm{Dn}_{1} \mathrm{Dt}_{1} \mathrm{~V}_{2}$ \\
\hline
\end{tabular}

\section{Discussions}

The addition of nitrogen fertiliser increased number of days to anthesis of wheat, and this may be attributed to prolonged vegetative growth stage at tillering stage. However, nitrogen had no effect on 
number of days to emergence and physiological maturity of wheat. Over the two years, nitrogen application significantly affected plant height of wheat genotypes, with the tallest plants recorded at the nitrogen dose of $125 \mathrm{~kg} / \mathrm{ha}$. At the rate of $125 \mathrm{~kg} / \mathrm{ha}$, nitrogen was enough to increase the protein content of the cells, as a result cell size increased, evident by more crop growth rate, consequently the leaf area enlarged, and photosynthetic activity increased and ultimately plant height increased as well. The results of increased plant height at higher nitrogen level are supported by previous studies $[16,17]$. The nitrogen application at $125 \mathrm{~kg} / \mathrm{ha}$ also influenced leaf dry mass, crop growth rate and net assimilation rate.

The wheat crops planted late took longer to emerge than those planted on early during both seasons. Delayed emergence may be due to slightly lower average minimum temperature compared to those of April. Normally when temperatures go down the process of germination becomes slow and ultimately the crown root initiation stage is prolonged, resulting in delayed emergence. Earlier research has demonstrated that growth of later-planted wheat is generally slower because of lower temperatures [18], and this might have contributed to significantly longer days to emergence by seedlings planted late. The results agree with [19] who found that early sowing had significantly maximum plant height and grain yield.

The earlier planted plants took more time to reach anthesis and physiological maturity than those planted late. This is probably because of lower temperatures in the month of July coinciding with anthesis period for the 21st April sowing date which probably lowered photosynthetic activity which resulted in delayed anthesis and physiological maturity. The results agree with findings [20], who found that longer maturity period was taken by early planted crops. In addition, [21] reported similar findings of longer physiological maturity with earlier planting due to effect of lower temperature and more grain filling time. In this study, planting date did not have a significant effect on crop growth rate, although the crop growth rate value was maximum at flowering. It is therefore unlikely that vigorous vegetative growth might be the cause for delayed anthesis and physiological maturity, hence the lower temperature effect is probable.

The higher grain protein content (GPC) was recorded during the early planting suggesting that grain filling period was longer at the earlier sowing, and more assimilates, together with vegetative nitrogen, was channelled to grains resulting in improved grain protein content. [22] reported that the highest grain protein content and grain yield can be produced by planting wheat crop at proper sowing time. The results of increased protein content agree with earlier planting studies by [23,24]. The highest grain protein content was observed with the application of $125 \mathrm{~kg} / \mathrm{ha} \mathrm{N}$ compared to the control. This showed that wheat genotypes needed the application of nitrogen to increase protein content, hence the gluten content, which is needed for good break making. [25] observed that nitrogen rate significantly improved wheat grain yield, grain protein content and protein yield.

The two wheat genotypes were clustered in a dendrogram showing protein band size similarities based on the 40 treatments of the current study using Un-weighted Pair Group Method with Arithmetic mean cluster analysis (UPGMA). From the four main clusters demarcated at coefficient of $\approx 0.63$, the highest number of treatment interactions was recorded in main cluster 3 . The protein bands identified were of 
sizes 25, 32, 58, and $75 \mathrm{kDa}$, and these results suggest the presence of Low Molecular Weight (LMW) and High Molecular Weight (HMW) glutenin in the cluster 3 treatments. The sub-clusters of main cluster 3 were grouped into $A$ to $F$, on which demarcation of treatments was at coefficient 0.88 or more, implying that they share at least $88 \% \mathrm{HMW}$ and/or LMW protein bands amongst them. Studies have shown that the HMW glutens have the highest influence on the rheological properties of dough and bread-making quality $[26,27]$.

The main cluster 2 comprised of only one treatment interaction, and the binary data matrix analysis of this cluster was able to identify protein band sizes of 22,46 , and $58 \mathrm{kDa}$, thus, classifying them mainly as low molecular weight glutenin. The main cluster 1 showed that the treatment interaction contained protein of band sizes 11 to $58 \mathrm{kDa}$, suggesting that they are low molecular weight protein glutenin's. The Low Molecular Weight glutenin's have been documented to contain Glu-A3d, Glu-B3b and Glu-B3g subunits, which are associated with good baking quality $[7,28]$. In the main cluster 4 , the proteins detected were of sizes $17,22,32,46,58$, and $75 \mathrm{kDa}$, suggesting presence of both HMW glutenin and LMW glutenin's. Normally all the HMW and LMW sub-units are bound together in glutenin polymers, the size and composition are strongly associated with gluten quality [29]. [8] found that the microstructure of glutens and HMW-GS/LMW-GS ratios were associated with bread-making quality of wheat varieties.

The highest number of protein bands were observed in sub-cluster $F$, characterised by (all Baviaans genotypes), represented by treatments $N_{125} D n_{1} D t_{1} V_{2}, N_{75} D n_{2} D t_{1} V_{2}$, and $N_{0} D n_{1} D t_{2} V_{2}$. Sub cluster $E$ also contained equally many protein bands (16) as the sub cluster $F$, and together they account for $47 \%$ of the total protein bands (33/70). Both sub-clusters contain the $125 \mathrm{~kg}$ of $\mathrm{N}$ which contributed most to the protein bands. In wheat flour baking quality normally increase with protein level, so the dominance of 125 $\mathrm{kg} / \mathrm{ha} \mathrm{N}$ in the clustering of protein bands may indicate good baking quality for such cluster members. Therefore, the effect of genotype (all Baviaans at sub-cluster F) and nitrogen (dominance of $125 \mathrm{~kg} / \mathrm{ha}$ of $\mathrm{N}$ at both cluster $\mathrm{E}$ and $\mathrm{F}$ ), and 21 st April planting date (16 bands from sub-cluster $\mathrm{E}$ ) seem to have played a bigger role in clustering of protein bands.

\section{Conclusions}

The application of $125 \mathrm{~kg} / \mathrm{ha}$ nitrogen significantly increased the number of days to anthesis, grain protein content and plant height. The interaction of plant population, planting time and nitrogen at 125 $\mathrm{kg} / \mathrm{ha}$ contributed more protein bands with low and high molecular weight glutenin's and that would produce wheat flour with good baking qualities in the wheat genotypes.

\section{Declarations}

Author Contributions: Supervision SN and FPM, Conceptualization SN, PM, and FPM. PM Investigation, field, and laboratory experiments. SN, FPM and PM data analysis, writing - Original Draft Preparation. All authors participated in the review and final improvement of the manuscript. 
Data Availability Statement: Data sets analysed during the study are available from the author on request.

Funding: This research did not receive any specific grant from funding agencies, as it was self-funded by the first author as a PhD student.

Institutional Review Board Statement: Not applicable

Informed Consent Statement: Not applicable

Conflicts of Interest: The authors declare no conflict of interest

\section{References}

1. Hussain, l.; Khan, M.A.; Khan, E.A. Bread wheat varieties as influenced by different nitrogen levels. J. Zhejiang Univ. Sci. B. 2006, 7, 70-78, doi:10.1631/jzus.2006.B0070.

2. Woyema A, B.G. and A.T. Effect of Different Nitrogen Fertilizer Rates on Yield. African J. food,agriculture,Nutrition Dev. 2012, 12, 6079-6094.

3. Zecevic, V.; Boskovic, J.; Knezevic, D.; Micanovic, D. Effect of seeding rate on grain quality of winter wheat. Chil. J. Agric. Res. 2014, 74, 23-28, doi:10.4067/S0718-58392014000100004.

4. Kausar, F.; Shahbaz, M. Interactive effect of foliar application of nitric oxide (NO) and salinity on wheat (Triticum aestivum L.). Pakistan J. Bot. 2013, 45, 67-73.

5. Rasheed, A.; Xia, X.; Yan, Y.; Appels, R.; Mahmood, T.; He, Z. Wheat seed storage proteins: Advances in molecular genetics, diversity and breeding applications. J. Cereal Sci. 2014, 60, 11-24, doi:10.1016/j.jcs.2014.01.020.

6. Šimić, G.; Horvat, D.; Jurković, Z.; Drezner, G.; Novoselović, D.; Šimić, G.; Horvat, D.; Jurković, Z.; Drezner, G.; Novoselović, D.; et al. the Genotype Effect on the Ratio of Wet Gluten Content To Total Wheat Grain Protein. J. Cent. Eur. Agric. 2006, 7, 13-18, doi:10.5513/jcea.v7i1.350.

7. Branlard, G.; Dardevet, M.; Amiour, N.; Igrejas, G. Allelic diversity of HMW and LMW glutenin subunits and omegagliadins in French bread wheat (Triticum aestivum L.). Genet. Resour. Crop Evol. 2003, 50, $669-679$.

8. Dhaka, V.; Khatkar, B.S. Effects of gliadin/glutenin and HMW-GS/LMW-GS ratio on dough rheological properties and bread-making potential of wheat varieties. J. Food Qual. 2015, 38, 71-82, doi:10.1111/jfq.12122.

9. Zhang, J.; Dong, S.; Dai, X.; Wu, T.; Wang, X.; Bai, H.; Wang, L.; He, M. Combined effect of plant density and nitrogen input on grain yield, nitrogen uptake and utilization of winter wheat. Vegetos 2016, 29, 63-73, doi:10.5958/2229-4473.2016.00023.9.

10. Wiersma, J. Determining an Optimum Seeding Rate for Spring Wheat in Northwest Minnesota. Crop Manag. 2002, 18, 1-7. 
11. C.L.Beadle Plant Growth Analysis. In Techniques In Bioproductivity And Photosynthesis; Coombs, J., Hall, D.O., Long, S.P., J.M.O. Scurlock, Eds.; Pergamon: Oxford, 1985; pp. 20-25.

12. Hunt, R. Plant Growth Analysis; Edward Arnold: London, 1978;

13. Tecator, A.B. Determination of keldahl nitrogen content with kjeltec autosystem I, II, III, and IV. Tecator application note; Sweden, 1991;

14. Winkleman, G.E..; Amin, R..; Rice, W.A.; Tahir, M.B. Methods Manual Soil Laboratory, Islamabad, 1990;

15. Rohlf, F.. NTSYS-pc: Numerical Taxonomy and Multivariate Analysis System Version 2.1; Exeter Publishing Setauket: New York, 2000;

16. Baloch, M.S.; Shah, I.T.H.; Nadim, M.A.; Khan, M.I.; Khakwani, A.A. Effect of seeding density and planting time on growth and yield attributes of wheat. J. Anim. Plant Sci. 2010, 20, 239-240.

17. Aslam, M.; Sanghi, A.H.; Khalid, L.; Javed, S. Effect of different doses of nitrogen on the yield of different cotton varieties. Asian J. Agric. Biol. 2013, 1, 179-182.

18. Qasim, M.; Qamer, M.; Faridullah; Alam., M. Sowing dates effect on yield and yield components of different wheat varieties. J. Agric. Res. 2008, 46, 135-140.

19. Hameed, E.;. W.A.S.;. A.A.S.;. J.B.;. T.M. Effect of Different Planting Dates, Seed Rate and Nitrogen Levels on Wheat. Asian J. Plant Sci. 2003, 2, 467-474.

20. Sial, M.A.; Dahot, M.U.; Arain, M.A.; Mangrio, S.M.; Naqvi, M.H.; Nizamani, N.A. Effect of time of planting and heat stresses on wheat advanced genotypes. Pakistan J. Biotechnol. 2005, 2, 13-23.

21. Sandhu, I.S.; Sharma, A.R.; Sur, H.S. Yield performance and heat unit requirement of wheat (Triticum aestivum) varieties as affected by sowing dates under rainfed conditions. Indian J. Agric. Sci. 1999, $69,175-179$.

22. Yan, C.; Zhang, Y.; Zhang, D.; Dang, J. Effects of sowing date and planting density on the grain' s protein component and quality of strong and medium gluten winter wheat cultivars. J. Appl. Ecol. $2008,19,1733-1740$.

23. El-Gizawy, N.K.B. Effect of planting date and fertilizer application on yield of wheat under no till system. World J. Agric. Sci. 2009, 5, 777-783.

24. Eslami, H.; Hadi, S.; Arabi, M. Effect of Planting Date on Protein content of Wheat varieties. Int. J. Farming Allied Sci. 2014, 3, 362-364.

25. Walsh, O.S.; Walsh, W.L. Seeding rate and nitrogen fertilizer rate effect on dryland no-till hard red spring wheat yield and quality. Agrosystems, Geosci. Environ. 2020, 3, 1-10, doi:10.1002/agg2.20001.

26. Zheng, W.; Peng, Y.; Ma, J.; Appels, R.; Sun, D.; Ma, W. High frequency of abnormal high molecular weight glutenin alleles in Chinese wheat landraces of the Yangtze-River region. Cereal Sci. 2011, 54, 401-408.

27. Hernández, Z.J.E.; Figueroa, J.D.C.; Rayas-Duarte, P.; Martínez-Flores, H.E.; Arámbula, G.V.; Luna, G.B.; R.J. Peña Influence of high and low molecular weight glutenins on stress relaxation of wheat kernels and the relation to sedimentation and rheological properties. J. Cereal Sci. 2012, 55, 344-350. 
28. Liang, D.; Tang, J.; Peña, R.J.; Singh, R.; He, X.; Shen, X.; Yao, D.; Xia, X.; He, Z. Characterization of CIMMYT bread wheats for high- and low-molecular weight glutenin subunits and other quality-related genes with SDS-PAGE, RP-HPLC and molecular markers. Euphytica 2010, 172, 235-250, doi:10.1007/s10681-009-0054-x.

29. Lew, E.; Kuzmicky, D.; Kasarda, D. Characterization of low molecular weight glutenin subunits by reversed-phase high-performance liquid chromatography, sodium dodecyl sulfate-polyacrylamide gel electrophoresis, and N-terminal amino acid sequencing. Cereal Chem. 1992, 69, 508-515.

\section{Figures}

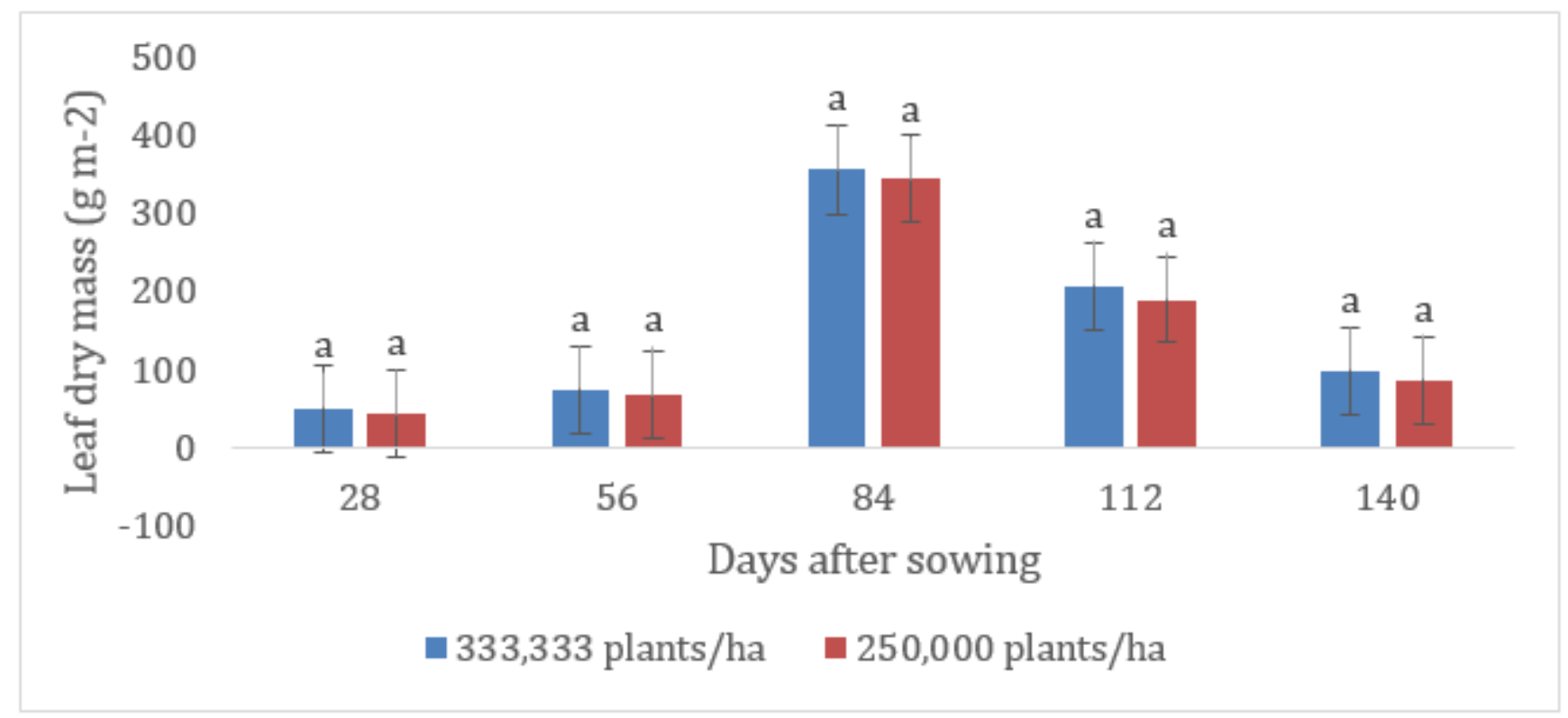

Figure 1

Effect of plant density on leaf dry mass $\left(\mathrm{g} \mathrm{m}^{-2}\right)$ of wheat during 2015 


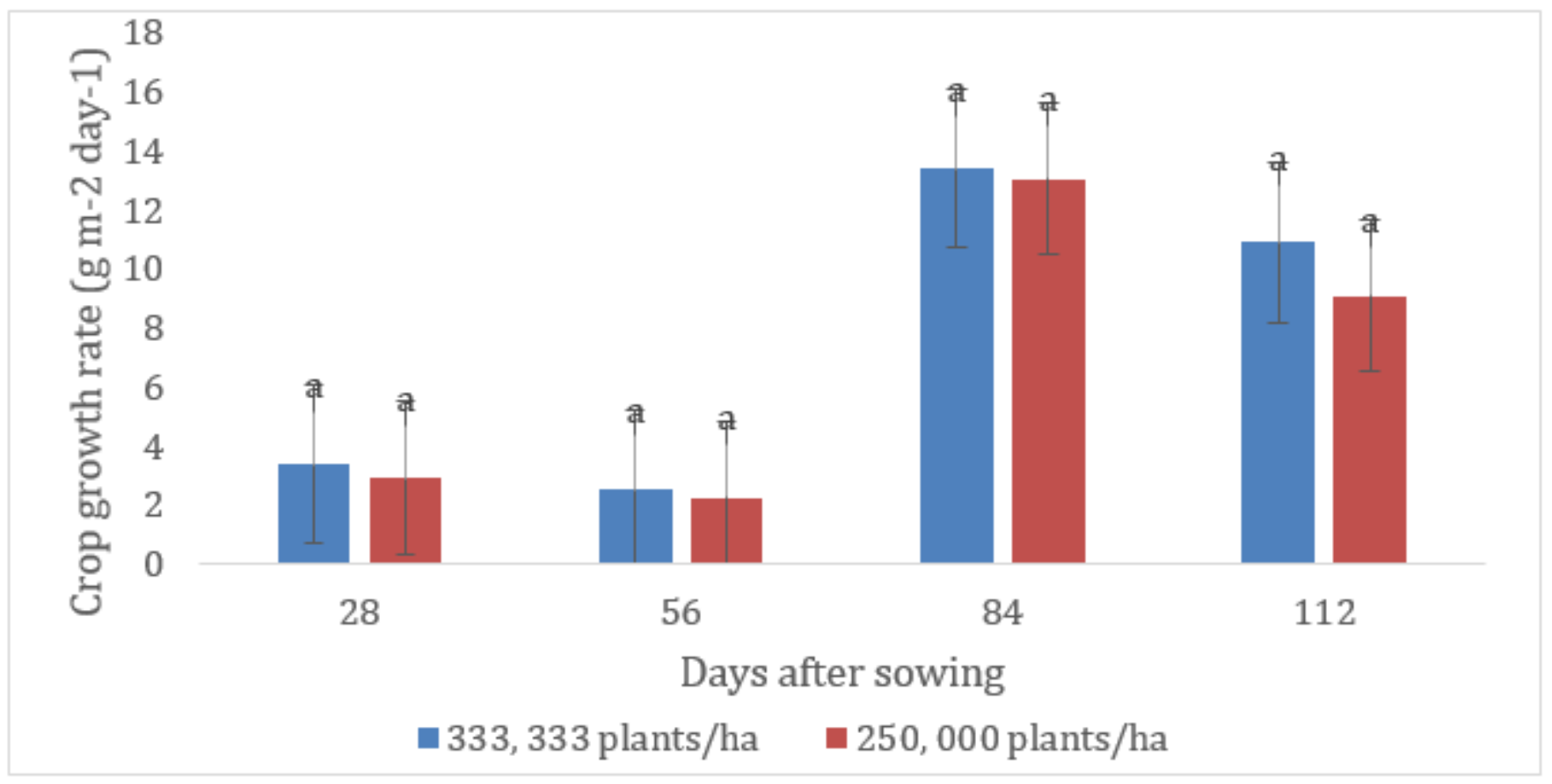

Figure 2

Effect of plant density on crop growth rate $\left(\mathrm{g} \mathrm{m}^{-2}\right.$ day $\left.^{-1}\right)$ in wheat during 2015
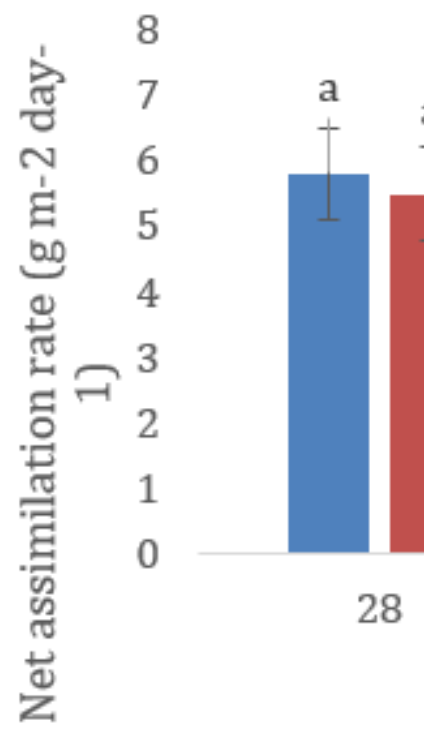

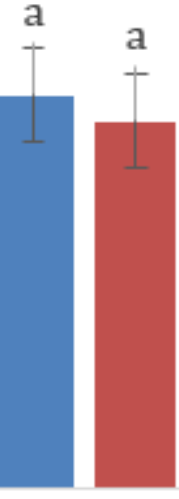

84

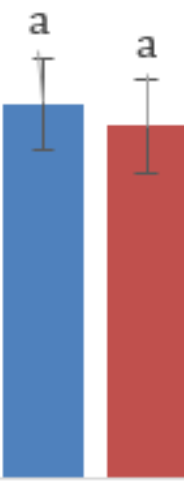

112

Days after sowing

- 333,333 plants/ha $\quad$-250,000 plants/ha

Figure 3

Effect of plant density on net assimilation rate $\left(\mathrm{g} \mathrm{m}^{-2}\right.$ day $\left.^{-1}\right)$ in wheat genotypes from 28 to 112 DAS during 2015. 


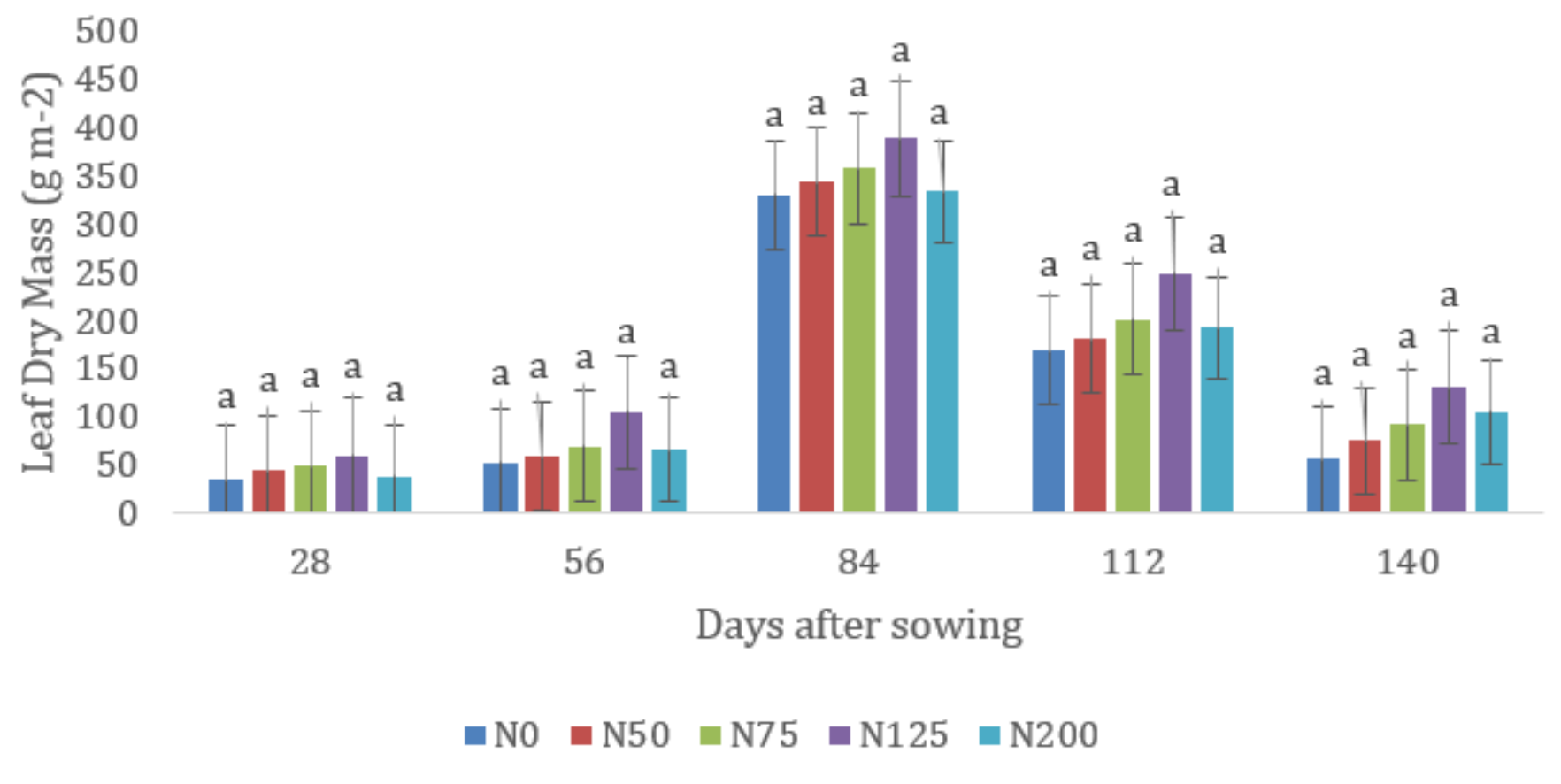

Figure 4

Effect of nitrogen doses on leaf dry mass $\left(\mathrm{g} \mathrm{m}^{-2}\right)$ in wheat during 2015.

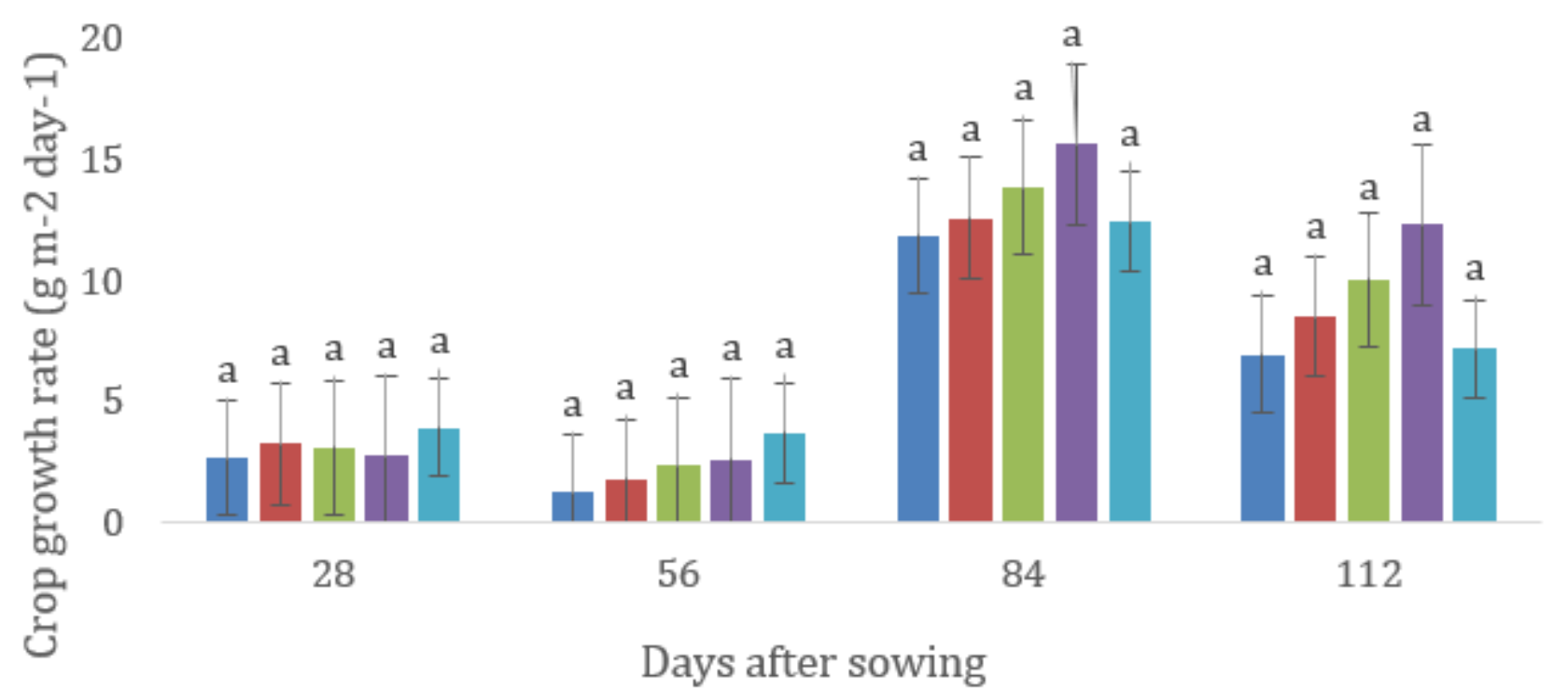

$\square$ N0 $\square$ N50 $=$ N75 $\square$ N125 $=\mathrm{N} 200$

Figure 5

Effect of nitrogen on crop growth rate $\left(\mathrm{g} \mathrm{m}^{-2}\right.$ day $\left.^{-1}\right)$ in wheat during 2015 


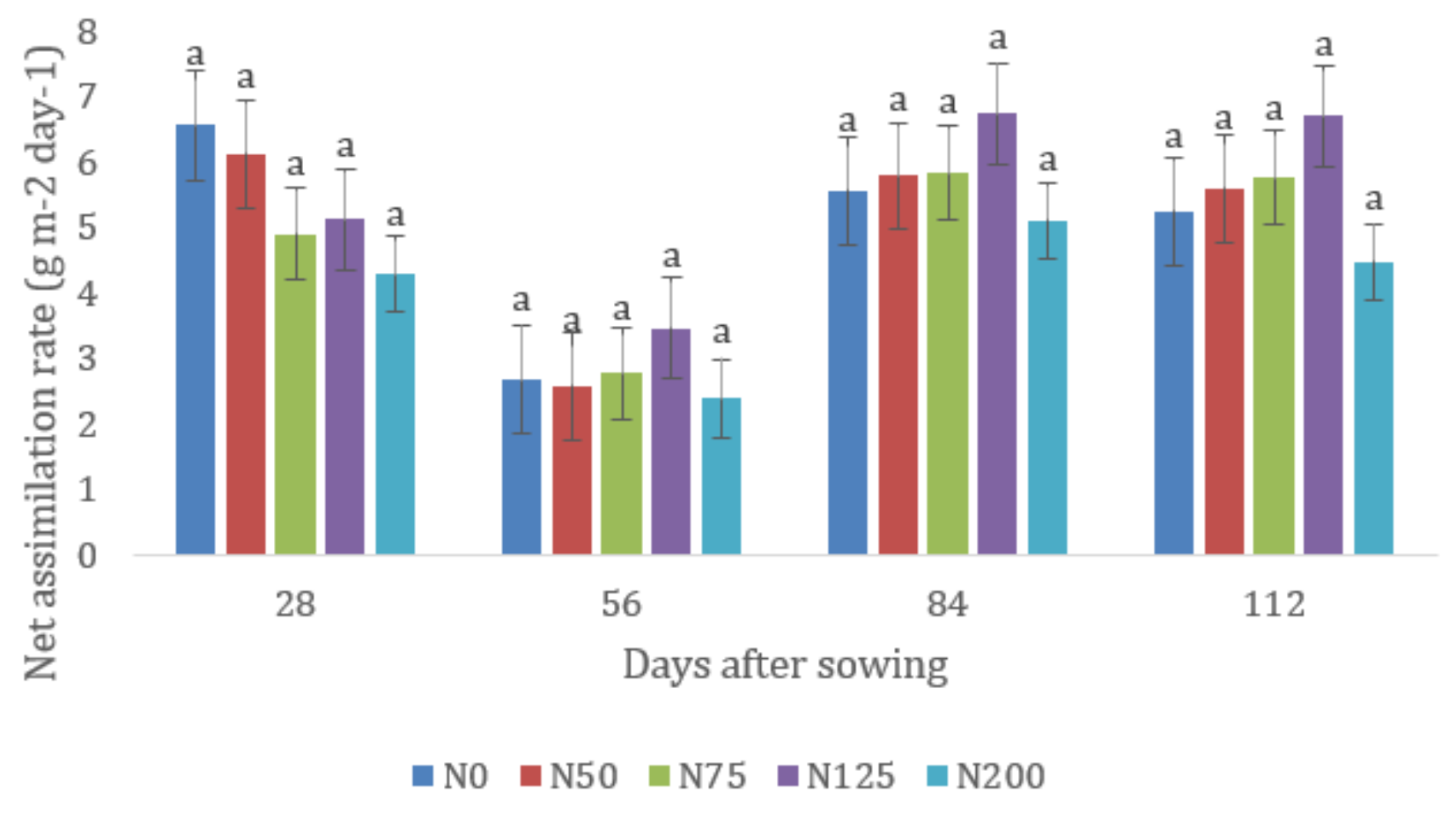

Figure 6

Effect of nitrogen on net assimilation rate $\left(\mathrm{g} \mathrm{m}^{-2}\right.$ day $\left.^{-1}\right)$ in wheat during 2015 


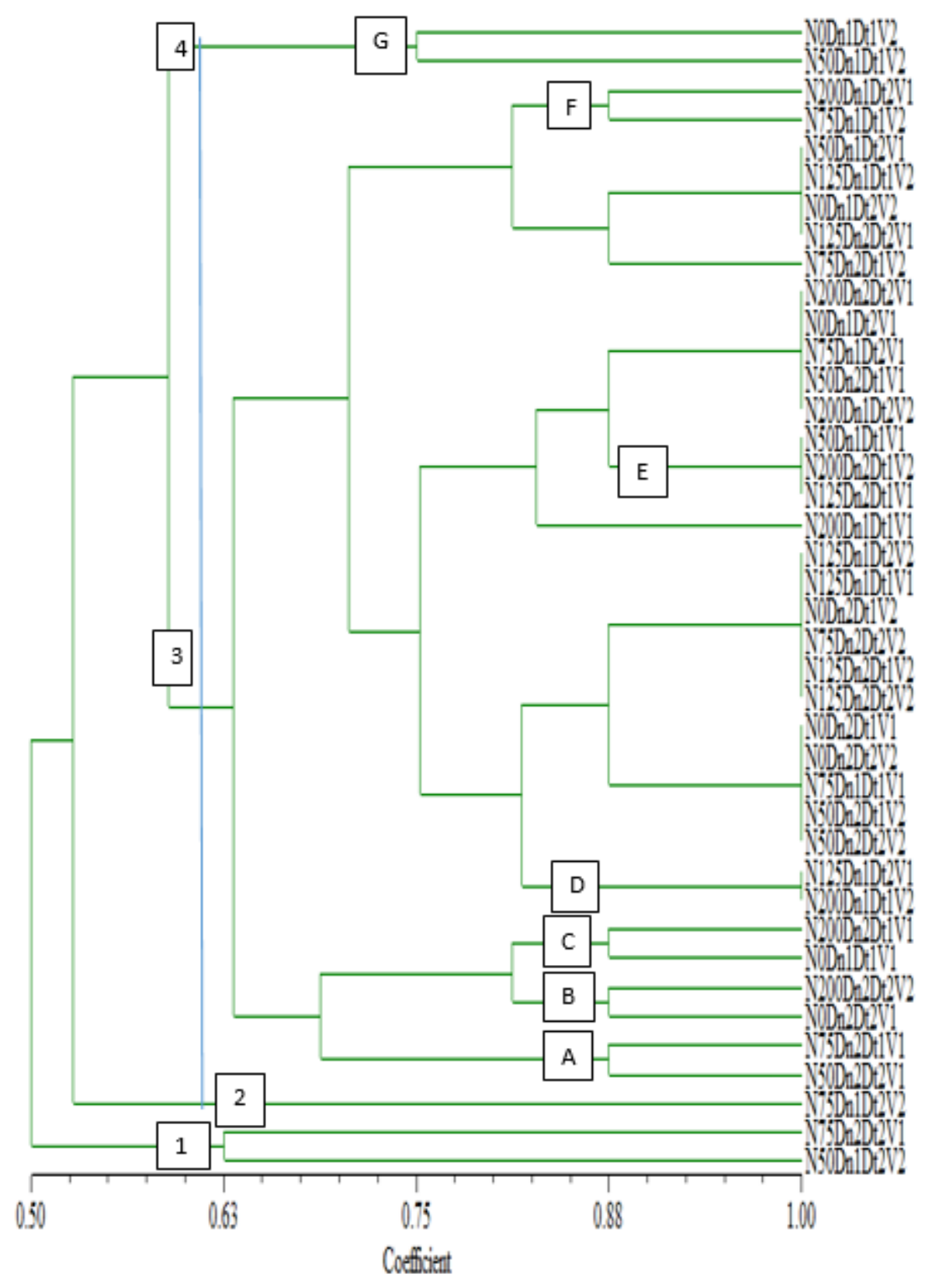

Figure 7

Dendrogram of two wheat genotypes showing protein size similarities based on 40 treatments ( $\mathrm{Y}$-axis), using UPGMA cluster analysis. The X-axis shows similarity coefficients between treatments. Labels 1 to 4 shows main clusters demarcated at 0.63 coefficient. $\left(N=\right.$ Nitrogen, $D_{n}=$ Plant Density, $D_{t}=$ Planting time, $V=$ Genotypes) 


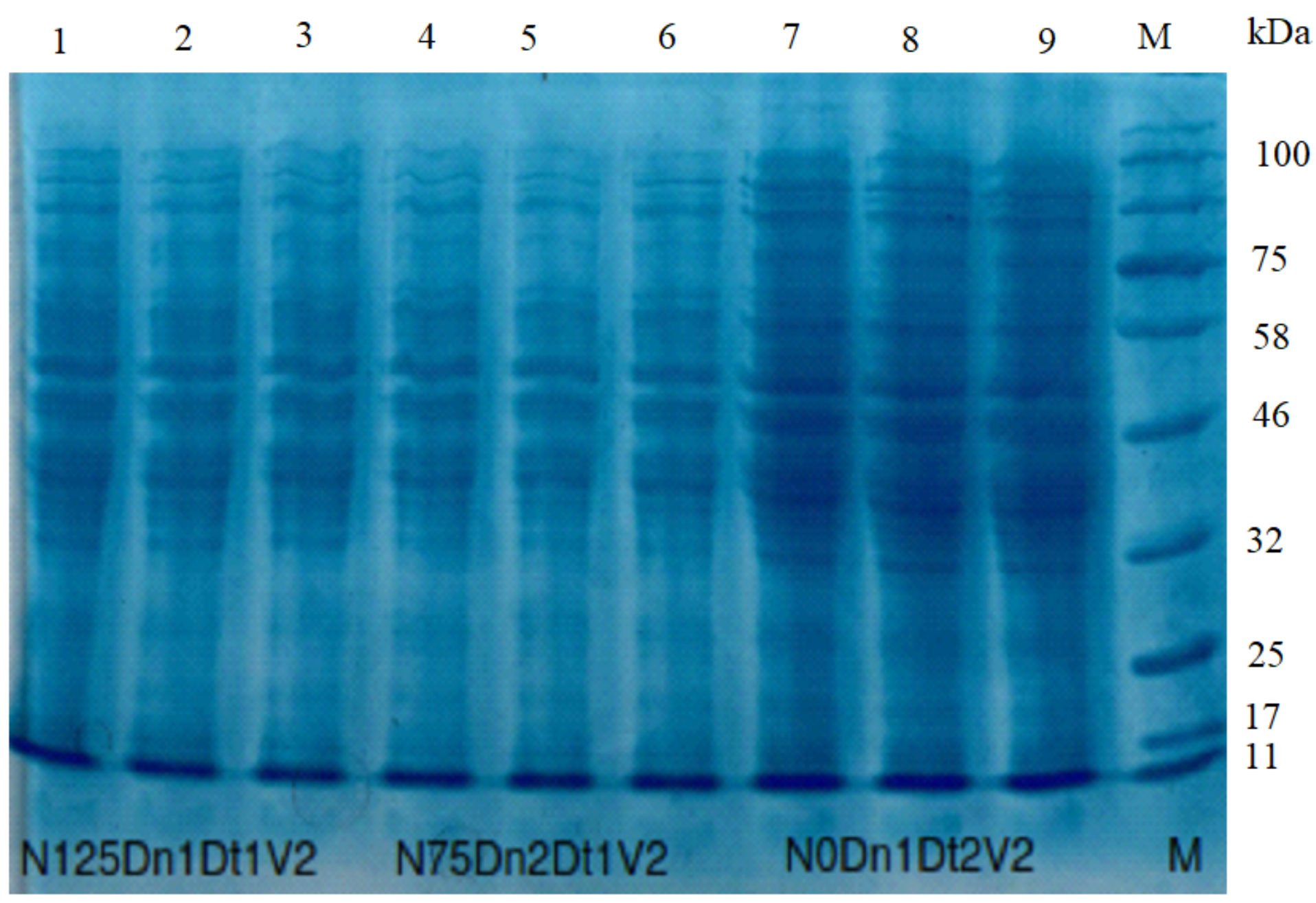

Figure 8

One dimensional SDS-PAGE separation of proteins of wheat genotype 14SAWYT308. Molecular weight maker was represented by label $\mathrm{M}$. 